\title{
Toward inventory-based estimates of soil organic carbon in forests of the United States
}

\author{
G. M. Domke, ${ }^{1,5}$ C. H. Perry, ${ }^{1}$ B. F. Walters, ${ }^{1}$ L. E. Nave, ${ }^{2}$ C. W. Woodall,${ }^{3}$ and C. W. Swanston ${ }^{4}$ \\ ${ }^{1}$ USD A Forest Service, Northern Research Station, 1992 Folwell Avenue, St. Paul, Minnesota 55108 USA \\ ${ }^{2}$ University of Michigan Biological Station, 9133 Biological Road, Pellston, Michigan 49769 USA \\ ${ }^{3}$ USD A Forest Service, Northern Research Station, 271 Mast Road, Durham, New Hampshire 03824 USA \\ ${ }^{4}$ USDA Forest Service, Northern Research Station, 410 MacInnes Drive, Houghton, Michigan 49931 USA
}

\begin{abstract}
Soil organic carbon (SOC) is the largest terrestrial carbon (C) sink on Earth; this pool plays a critical role in ecosystem processes and climate change. Given the cost and time required to measure SOC, and particularly changes in SOC, many signatory nations to the United Nations Framework Convention on Climate Change report estimates of SOC stocks and stock changes using default values from the Intergovernmental Panel on Climate Change or country-specific models. In the United States, SOC in forests is monitored by the national forest inventory (NFI) conducted by the Forest Inventory and Analysis (FIA) program within the U.S. Department of Agriculture, Forest Service. The FIA program has been consistently measuring soil attributes as part of the NFI since 2001 and has amassed an extensive inventory of SOC in forest land in the conterminous United States and southeast and southcentral coastal Alaska. That said, the FIA program has been using country-specific predictions of SOC based, in part, upon a model using SOC estimates from the State Soil Geographic (STATSGO) database compiled by the Natural Resources Conservation Service. Estimates obtained from the STATSGO database are averages over large map units and are not expected to provide accurate estimates for specific locations, e.g., NFI plots. To improve the accuracy of SOC estimates in U.S. forests, NFI SOC observations were used for the first time to predict SOC density to a depth of $100 \mathrm{~cm}$ for all forested NFI plots. Incorporating soil-forming factors along with observations of SOC into a new estimation framework resulted in a $75 \%$ (48 $\pm 0.78 \mathrm{Mg} / \mathrm{ha}$ ) increase in SOC densities nationally. This substantially increases the contribution of the SOC pool, from approximately $44 \%(17 \mathrm{Pg})$ of the total forest ecosystem C stocks to $56 \%(28 \mathrm{Pg})$, in the forest $\mathrm{C}$ budget of the United States.
\end{abstract}

Key words: climate; Forest Inventory and Analysis; greenhouse gas inventory; International Soil Carbon Network; modeling; national forest inventory.

\section{INTRODUCTION}

Soil organic carbon (SOC) is the largest terrestrial carbon (C) sink, and management of this pool is a critical component of efforts to mitigate atmospheric $\mathrm{C}$ concentrations (Post et al. 1982, Jobbágy and Jackson 2000, Lal 2004, 2005, Tian et al. 2015). SOC also affects essential biological, chemical, and physical soil functions such as nutrient cycling, water retention, and soil structure (Lal 2001, Jandl 2014). Globally, SOC stock estimates range from 425 to $2111 \mathrm{Pg}$ in the first $100 \mathrm{~cm}$ (Tian 2015). Much of this SOC is found in forest ecosystems (Lal 2005) and is thought to be relatively stable. However, there is growing evidence that $\mathrm{SOC}$ is sensitive to global change effects, particularly land use histories, resource management, and climate (Jobbágy and Jackson 2000, Guo and Gifford 2002, Davidson and Janssens 2006, Heimann and Reichstein 2008, Nave et al. 2010, Nave et al. 2013, Tian et al. 2015).

Manuscript received 15 July 2016; revised 9 December 2016; accepted 21 December 2016. Corresponding Editor: A. David McGuire.

${ }^{5}$ E-mail: gmdomke@fs.fed.us
Inventories of SOC are necessary for soil quality assessments (Sikora and Stott 1996) and to predict C cycling (Ellert et al. 2002). But given the cost and time required to measure SOC, many signatory nations to the United Nations Framework Convention on Climate Change report estimates of SOC stocks and stock changes using default values from the Intergovernmental Panel on Climate Change (IPCC 2006) or country-specific models (Kurz and Apps 2006, Keith et al. 2009). Countryspecific models may be developed using estimates from landscape models (Thompson and Kolka 2005), digital terrain models (Zushi 2006), or from data obtained directly from soil inventories. Oftentimes, soil inventories are not representative of all land uses and vegetation types, resulting in unquantified uncertainties in countryspecific models (Amichev and Galbraith 2004). In the United States, SOC in forests is monitored by the national forest inventory (NFI) conducted by the Forest Inventory and Analysis (FIA) program within the U.S. Department of Agriculture, Forest Service (O'Neill et al. 2005). The FIA program currently uses SOC predictions based, in part, upon a model using SOC estimates from the State Soil Geographic (STATSGO) database compiled by the 
Natural Resources Conservation Service (NRCS; Schwarz and Alexander 1995, Amichev and Galbraith 2004), hereafter referred to as the country-specific model. The STATSGO estimates of SOC are averages over large map units and are not expected to provide accurate estimates of SOC for specific locations (Homann et al. 1998). Furthermore, some STATSGO estimates are based upon expert judgment and/or lack systematic field observations (Amichev and Galbraith 2004), but the countryspecific model predictions based on these estimates have been used in past United Nations Framework Convention on Climate Change reporting (EPA 2015).

The FIA program has been consistently measuring soil attributes as part of the NFI since 2001 and has amassed an extensive inventory of SOC observations in forest land in the conterminous United States and southeast and southcentral coastal Alaska (O'Neill et al. 2005). Soil samples are collected on a subset of NFI plots, and soil cores are taken to a depth of $20.32 \mathrm{~cm}$ on each of these plots. In an effort to improve the accuracy and precision of SOC estimates in forest land in the United States, a modeling framework developed to predict litter carbon stocks (Domke et al. 2016) was expanded to predict SOC using observations from the NFI and the International Soil Carbon Network (ISCN, http://iscn.fluxdata.org/ data/access-data/) database, along with auxiliary climate, soil, and topographic variables for United Nations Framework Convention on Climate Change reporting. Specifically, we (1) evaluate the NFI observations of SOC in the United States, (2) develop SOC density profiles to depths of 30 and $100 \mathrm{~cm}$ for forest land using in situ observations from the NFI and ISCN, (3) compare the country-specific model predictions to the NFI observations and new model predictions, and (4) expand the SOC density predictions from the subset of NFI plots to all forested plots for use in United Nations Framework Convention on Climate Change reporting.

\section{Methods}

We first examined country-specific predictions of SOC density using estimates in the NFI. We then evaluated approaches to replace the SOC model predictions in United Nations Framework Convention on Climate Change reporting with a model developed from the most recent annual NFI data and observations from the ISCN. This work was restricted to the annual inventory where SOC attributes were measured (2001-2012); the annual inventory includes a nationally consistent sampling frame and plot design so the methodologies established for replacing the country-specific model predictions of SOC could be applied nationally to enable stockdifference $\mathrm{C}$ accounting.

The country-specific SOC density predictions were compiled by spatially relating SOC estimates from STATSGO map units to FIA forest type groups and area expansion factors on each plot using the following model (Amichev and Galbraith 2004):

$$
\mathrm{CS}=\left(\sum_{F=1}^{j}\left(\operatorname{SOC}_{\mathrm{STATSGO}} \times E\right)\right) \times\left(\sum_{F=1}^{j}(E)\right)^{-1}
$$

where CS was the county-specific SOC density by forest type group $(\mathrm{Mg} / \mathrm{ha}), \mathrm{SOC}_{\mathrm{STATSGO}}$ was the mass $\mathrm{SOC}$ from the STATSGO map unit ( $\mathrm{Mg} / \mathrm{ha}), E$ was the expansion factor to relate the area represented by each FIA plot, and $F$ was the number of FIA plot records with the same forest type group $(F=1,2,3, \ldots, j)$. Forest type group is a broad aggregation of forest types that best describe the predominant tree species (or group of tree species) on each condition (i.e., domains mapped on each plot using land use, forest type, stand size, ownership, tree density, stand origin, and/or disturbance history; there may be multiple conditions on a single inventory plot) that are not overtopped on each FIA plot (USDA Forest Service 2015). For a complete list of forest type groups, see USDA Forest Service (2015).

\section{Plot design and sampling}

The FIA program employs a multi-phase inventory, with each phase contributing to the subsequent phase. First, current aerial photography (e.g., National Agriculture Imagery Program, USDA Farm Services Agency [2011]) is used in a prefield process to determine the land use (e.g., forest or cropland) at all sampling points (i.e., plot locations). Next, each sample point is assigned to a stratum using imagery or thematic products (e.g., National Land Cover Database; Homer et al. 2012) obtained from satellites. A stratum is a defined geographic area (e.g., state or estimation unit) that includes plots with similar attributes; in many regions, strata are defined by predicted percent canopy cover. National base sample intensity permanent ground plots are distributed approximately every 2428 ha across the 48 conterminous states of the United States in four geographic regions (Fig. 1). Each permanent ground plot comprises a series of smaller fixed-radius $(7.32 \mathrm{~m})$ plots (i.e., subplots) spaced $36.6 \mathrm{~m}$ apart in a triangular arrangement with one subplot in the center. Tree- and site-level attributes, such as diameter at breast height (dbh) and tree height, are measured at regular temporal intervals on plots that have at least one forested condition defined in the prefield process (USDA Forest Service 2016). Soil samples are collected along with other non-standing tree ecosystem attributes (e.g., litter; Domke et al. 2016) on every 16th base intensity plot, where at least one forested condition exists, distributed approximately every 38848 ha (USDA Forest Service 2011). Soil samples are collected to a depth of $20.32 \mathrm{~cm}$ along a soil sampling transect adjacent to subplot 2. First, litter material (i.e., litter [Oi], fulvic [Oe], and humic layers $[\mathrm{Oa}])$ including woody fragments with large-end diameters of up to $7.5 \mathrm{~cm}$ (Domke et al. 2016) is removed along the soil sampling transect. Note that litter material is estimated separately and was not included in this analysis (Domke et al. 2016). Second, soil cores are taken at the soil sampling transect location using a soil core sampler 

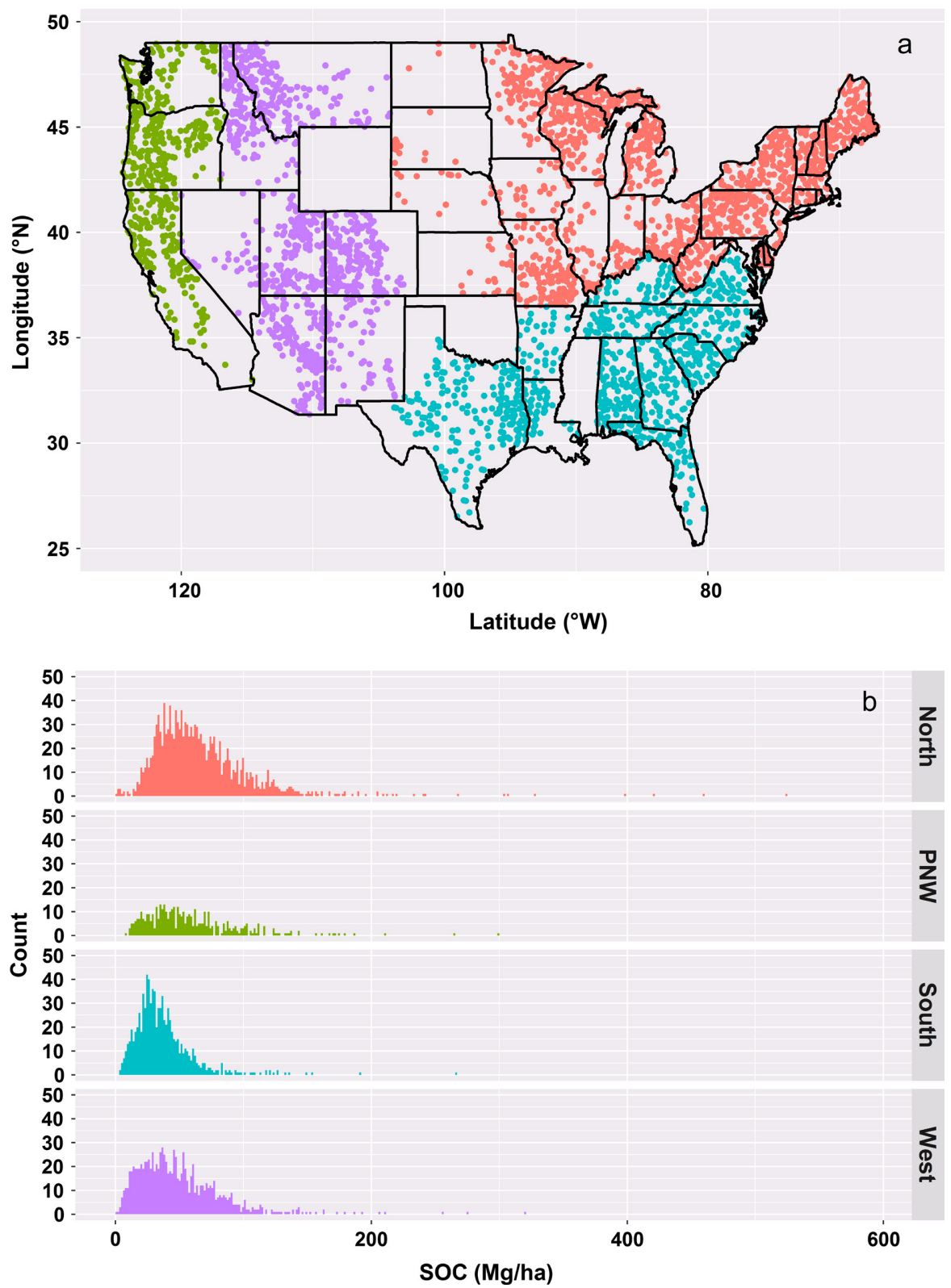

FIG. 1. Distributions of National Forest Inventory (NFI) plots by region in the conterminous United States that have at least one forested condition and include measurements of soil attributes $(n=3636)$. Note that plot locations are approximate. SOC, soil organic carbon; PNW, Pacific Northwest. [Colour figure can be viewed at wileyonlinelibrary.com]

and slide hammer. Third, the soil is removed from the soil coring head and sliced with a knife at the intersection of the two soil core liners, each $10.16 \mathrm{~cm}$ long. Fourth, the soil in each soil liner is removed and bagged. Finally, the texture of each soil layer is estimated in the field, and physical and chemical properties are determined in regional laboratories (USDA Forest Service 2011).

\section{Data}

Soil samples are analyzed for bulk density, water content, total C, and total nitrogen (N) (Amacher et al. 2003, O'Neill et al. 2005) and the laboratory results are managed as part of the Soils Lab Table (SOILS_LAB) in the publicly available FIA database (data available online). ${ }^{6}$ Bulk density was calculated as the total oven-dried mass of all soil materials within a fixed volume (i.e., $5 \mathrm{~cm}$ diameter soil core; Amacher et al. 2003). There are estimates of coarse fragment content in the NFI database but this variable is quantified as mass. Absent estimates of the volume of coarse fragments it is not possible to adjust estimates of bulk density in our calculations. Total, organic, and

\footnotetext{
${ }^{6}$ http://apps.fs.fed.us/fiadb-downloads/datamart.html
} 
inorganic $\mathrm{C}$ and total nitrogen were determined through combustion methods on the fine earth fraction (soil materials passing a $2 \mathrm{~mm}$ sieve; Amacher et al. 2003). For this analysis, estimates of SOC from the FIA program were calculated following O'Neill et al. (2005)

$$
\mathrm{SOC}_{\mathrm{FIA}}=\mathrm{CP}_{i} \cdot \mathrm{BD}_{i} \cdot t_{i} \cdot \mathrm{ucf}
$$

where $\mathrm{SOC}_{\mathrm{FIA}}$ was the total mass $(\mathrm{Mg} / \mathrm{ha})$ of the mineral and organic soil $\mathrm{C}$ at the $i$ th layer, $\mathrm{CP}_{i}$ was the mass percent organic $\mathrm{C}$ in the fine earth fraction of the $i$ th layer, $\mathrm{BD}_{i}$ was the bulk density calculated as the mass of all soil materials per unit volume of the sample $\left(\mathrm{g} / \mathrm{cm}^{3}\right)$ at the $i$ th soil layer, $t_{i}$ was the thickness $(\mathrm{cm})$ of the $i$ th soil layer, either $0-10.16 \mathrm{~cm}$ or $10.16-20.32 \mathrm{~cm}$, and ucf was the unit conversion factor (100).

In the present study, there were 3636 profiles with 7038 SOC layer observations in the NFI data set; in some cases, only a single layer was available for a profile. Since the United States has historically reported SOC estimates to a depth of $100 \mathrm{~cm}$ (U.S. Environmental Protection Agency [US EPA] 2015), ISCN data from forest land in the United States were combined with the NFI soil layer observations to develop models of SOC by soil order to a depth of $100 \mathrm{~cm}$. Soil order for each NFI plot was obtained by intersecting exact NFI plot coordinates with STATSGO map units and assigning the most frequently occurring soil order to that map unit and the NFI plot that intersected that map unit. A small number of NFI plots intersected map units that were all water, ice, or other non-soil. For those plots, the nearest map unit that had a dominant soil order was assigned. While the ISCN database houses data from a variety of agency and academic sources, all observations used from the ISCN in this analysis were contributed by the NRCS, which assigns soil taxonomic classifications for most pedons in its characterization database. A total of 16504 soil layers from 2037 profiles were used from ISCN land uses defined as deciduous, evergreen, or mixed forest. The ISCN database computes the SOC stocks of individual soil layers from the $\mathrm{C}$ concentration, bulk density, and layer thickness data provided by contributors, and also assigns land cover classes (Multi-Resolution Land Characteristics Consortium 2011) for the locations of the profiles/layers. The data we accessed via ISCN were from the 2012 database version (ISCN 2012a, $b$ ). The FIA-ISCN harmonized data set used for model development and prediction included a total of 5673 profiles with 22342 layer observations at depths ranging from 0 to $1148 \mathrm{~cm}$.

\section{Model development}

The modeling framework developed to predict SOC in this study was built around strategic-level forest and soil inventory information and auxiliary variables available for all NFI plots in the United States. The first phase of the framework involved fitting linear and non-linear models using the mid-point of each soil layer from the harmonized data set and SOC observations at those mid-points to predict SOC to a depth of 30 and $100 \mathrm{~cm}$. Ten linear and non-linear models were evaluated, and a log-log model provided the best fit to the harmonized data

$$
\log _{10} \mathrm{SOC}=I+\log _{10} \text { Depth }
$$

where $\log _{10}$ SOC was the observed SOC density $(\mathrm{Mg}$ $\mathrm{C} \cdot \mathrm{ha}^{-1} \cdot \mathrm{cm}^{-1}$ ) at the midpoint depth, $I$ was the intercept, and $\log _{10}$ Depth was the profile mid-point depth $(\mathrm{cm})$. The model was validated by partitioning the complete harmonized data set 10 times into training (70\%) and testing groups $(30 \%)$ and then repeating this step for each soil order to evaluate model performance by USDA soil taxonomic order (Soil Survey Staff 1999). Extra sum of squares $F$ tests (Draper and Smith 1981) were used to evaluate whether there were statistically significant differences between the model coefficients from the model fit to the complete harmonized data set and models fit to subsets of the data by soil order. Model coefficients for each soil order were used to predict SOC for the layer $20.32-30 \mathrm{~cm}$ and $20.32-100 \mathrm{~cm}$ for all NFI plots with soil profile observations. Since logarithmic transformations are known to introduce a systematic bias into predictions (Sprugel 1983), correction factors calculated from the standard error of the estimate in the regressions were multiplied by the predictions to remove the bias for each soil type. Next, we summed the SOC layer observations from the NFI and the corrected predictions over 30 and $100 \mathrm{~cm}$ profiles for each NFI plot

$$
\mathrm{SOC}_{30}=\mathrm{SOC}_{\text {FIA_TOTAL }}+\mathrm{SOC}_{20-30}
$$

and

$$
\mathrm{SOC}_{100}=\mathrm{SOC}_{\text {FIA_TOTAL }}+\mathrm{SOC}_{20-100}
$$

where $\mathrm{SOC}_{30}$ and $\mathrm{SOC}_{100}$ were the total estimated SOC density from 0-30 and 0-100 cm, respectively for each forest condition with a soil sample in the NFI, SOC FIAITOTAL was the total observed SOC from 0 to $20.32 \mathrm{~cm}$ on NFI plots as estimated from model [2], and $\mathrm{SOC}_{20-30}$ and $\mathrm{SOC}_{20-100}$ were the predicted SOC from $20.32-30 \mathrm{~cm}$ and $20.32-100 \mathrm{~cm}$ from model [3]. While information on depth to restrictive layer was available for some FIA plots with soil samples, this was determined to not be a reliable variable and, since it was only available on plots with soil measurements, it was not used in this analysis. However, in the ISCN database, $82 \%$ of forest soil profiles utilized in our analysis are $\geq 1 \mathrm{~m}$ deep, suggesting that while our approach may overestimate soil depth and SOC density in some cases, the overall influence of this overestimation on overall and soil-orderspecific SOC estimates is likely modest.

In the second phase of the modeling framework, $\mathrm{SOC}_{30}$ and $\mathrm{SOC}_{100}$ estimates for the NFI plots were used to predict SOC for core plots lacking SOC estimates using random forests (RF) for regression, a machine learning tool that uses bootstrap aggregating (i.e., bagging) to develop models to improve prediction (Breiman 2001). Random forests also relies on random variable selection to develop a forest of uncorrelated regression trees. These 
TABLE 1. Summary statistics (mean and standard deviation [SD]) for soil organic carbon (SOC) density observations and forest site attributes by soil order from all National Forest Inventory (NFI) plots with soil samples in the United States.

\begin{tabular}{|c|c|c|c|c|c|c|c|c|c|}
\hline \multirow[b]{2}{*}{ Soil order } & \multirow[b]{2}{*}{$n$} & \multirow{2}{*}{$\begin{array}{l}\text { AGLTC } \\
(\mathrm{Mg} / \mathrm{ha})\end{array}$} & \multirow{2}{*}{$\begin{array}{c}\text { Basal } \\
\text { area }\left(\mathrm{m}^{2}\right)\end{array}$} & \multicolumn{6}{|c|}{ SOC (Mg/ha) } \\
\hline & & & & 1 & 2 & Total & SD & $\mathrm{CS}$ & SD CS \\
\hline$\overline{\text { All }}$ & 3,636 & 45.53 & 21.75 & 33.10 & 22.94 & 54.01 & 37.05 & 62.87 & 40.06 \\
\hline Alfisols & 894 & 45.87 & 21.31 & 31.06 & 20.24 & 49.51 & 28.47 & 59.14 & 36.37 \\
\hline Andisols & 133 & 81.25 & 30.24 & 34.83 & 27.10 & 60.24 & 41.25 & 69.39 & 26.53 \\
\hline Aridisols & 112 & 8.38 & 13.10 & 16.81 & 13.05 & 28.66 & 19.19 & 28.63 & 16.18 \\
\hline Entisols & 209 & 25.48 & 19.51 & 23.41 & 16.34 & 38.62 & 29.25 & 51.23 & 45.15 \\
\hline Histosols & 30 & 37.87 & 21.59 & 35.71 & 32.42 & 61.20 & 51.94 & 144.05 & 34.32 \\
\hline Inceptisols & 588 & 53.04 & 23.68 & 38.65 & 28.47 & 63.97 & 45.23 & 66.20 & 45.95 \\
\hline Mollisols & 586 & 28.51 & 18.77 & 34.14 & 24.83 & 56.46 & 32.49 & 47.16 & 28.45 \\
\hline Spodosols & 395 & 55.49 & 25.30 & 42.79 & 31.92 & 72.06 & 47.62 & 107.03 & 42.32 \\
\hline Ultisols & 680 & 53.48 & 21.78 & 29.97 & 17.53 & 46.31 & 30.94 & 57.37 & 22.07 \\
\hline Vertisols & 9 & 17.35 & 10.28 & 23.60 & 13.91 & 35.96 & 10.80 & 47.35 & 13.82 \\
\hline
\end{tabular}

Notes: AGLTC, aboveground live tree carbon stocks; SOC1, soil organic carbon in the top layer $(0-10.16 \mathrm{~cm})$; SOC 2, soil organic carbon in the second layer $(10.16-20.32 \mathrm{~cm})$; total SOC, mean SOC from layers 1 and 2; SD SOC, standard deviation of the mean (total SOC); CS SOC, country-specific soil organic carbon predictions $(0-100 \mathrm{~cm})$; SD CS SOC, standard deviation of the mean CS predictions.

trees uncover the relationship between a dependent variable, in this case $\mathrm{SOC}_{30}$ and $\mathrm{SOC}_{100}$, and a set of predictor variables. The RF analysis included publicly available, relevant predictor variables, those that may influence the formation, accumulation, and loss of SOC, from annual inventories collected on all core plots and auxiliary climate, soil, and topographic variables obtained from the PRISM Climate Group (data available online), ${ }^{7}$ NRCS (Schwarz and Alexander 1995), and U.S. Geological Survey (Danielson and Gesch 2011), respectively. To avoid problems with data limitations, variable pruning was used to reduce the RF models to the minimum number of relevant predictors without substantial loss in explanatory power or increase in root mean squared error (RMSE). The general form of the full RF models were

$$
\begin{aligned}
P(\text { SOC })= & f(\text { lat }, \text { lon, elev, fortypgrp, ppt }, \\
& \text { tmax }, \text { cmi, order, surfgeo })
\end{aligned}
$$

where lat is latitude, lon is longitude, elev is elevation, fortypgrp is forest type group, ppt is mean annual precipitation, tmax is average maximum temperature, climate moisture index (cmi) is the ratio of precipitation to potential evapotranspiration, order is soil order, and surfgeo is surficial geological description.

The NFI data set used to develop the full RF model was partitioned 10 times into training $(70 \%)$ and testing (30\%) groups and the results were evaluated graphically and with a variety of statistical metrics including Spearman's rank correlation, equivalence tests (Wellek 2003), as well as RMSE. All analyses were conducted using $\mathrm{R}$ statistical software, version 2.15.2 (R Development Core Team 2014).

\section{RaCA comparisons}

As a final step, RF model predictions of SOC were compared to the NRCS Rapid Assessment of U.S. Soil Carbon

${ }^{7} \mathrm{http}: / /$ prism.oregonstate.edu
(Soil Survey Staff 2013) estimates of SOC at 30 and $100 \mathrm{~cm}$ by NRCS Land Resource Regions (LRRs). First, RaCA estimates of SOC were joined to RaCA plot locations $(n=6215)$; note that some RaCA plots had no location information and/or estimates of SOC. Next, the RaCA data were sorted to isolate SOC predictions that were identified as occurring on forest land $(n=1713)$ based on the RaCA "land use/land cover" attribute assigned to each plot. The RaCA locations and RF model predictions were then assigned to LRRs in the 2006 MLRA Geographic Database, version 4.2 (USDA NRCS 2006) using ArcMap 10.3.1 (Environmental Systems Research Institute 2016, ArcGIS Desktop: Release 10.3.1., Redlands, CA, USA). Finally, the RaCA and RF model predictions of SOC were exported for comparison.

\section{RESUlTS}

\section{NFI observations}

Alfisols were the most common $(n=894)$ soil order sampled in the NFI, followed by Ultisols $(n=680)$, Inceptisols $(n=588)$, and Mollisols $(n=586)$. Estimates of SOC density obtained from measurements in the NFI $(0-20.32 \mathrm{~cm})$ ranged from $<1-524 \mathrm{Mg} / \mathrm{ha}$, with an estimated mean of $54 \pm 0.61 \mathrm{Mg} / \mathrm{ha}$ (mean $\pm \mathrm{SE}$ ). Spodosols had the highest SOC density at $72 \pm 2.40 \mathrm{Mg} / \mathrm{ha}$, while Aridisols had the lowest SOC density at $28 \pm 1.81 \mathrm{Mg} / \mathrm{ha}$ (Table 1). Gelisols and Oxisols were not sampled in the NFI. In all soil orders represented in the NFI, the top layer $(0-10.16 \mathrm{~cm})$ estimates of SOC were larger than the second layer (10.16-20.32 cm) (Table 1). Ultisols and Vertisols had among the lowest total SOC and had the largest decreases (27\%, 12 and $10 \mathrm{Mg} / \mathrm{ha}$, respectively) between layers 1 and 2. Histosols had the smallest decrease (5\%, $3 \mathrm{Mg} / \mathrm{ha}$ ) between layers 1 and 2, followed by Andisols and Aridisols (13\%, 7.73 and $3.75 \mathrm{Mg} / \mathrm{ha}$, respectively).

Regionally, the Northern United States had the most NFI observations $(n=1381)$ of SOC and the widest range 
TABLE 2. Linear regression results of SOC stocks by soil order using the harmonized NFI-ISCN data.

\begin{tabular}{lcccrrr}
\hline \hline Soil order & Intercept & Slope & $r^{2}$ & \multicolumn{1}{c}{$F$} & df & $P$ \\
\hline All & 1.1795 & -0.8228 & 0.56 & 29646.79 & 1,23537 & $<0.001$ \\
Alfisols & 1.1122 & -0.8330 & 0.64 & 10657.50 & 1,5893 & $<0.001$ \\
Andisols & 1.3837 & -0.8425 & 0.49 & 1185.78 & 1,1254 & $<0.001$ \\
Aridisols & 0.2065 & -0.1300 & 0.02 & 6.55 & 1,279 & 0.011 \\
Entisols & 0.9300 & -0.7207 & 0.39 & 752.34 & 1,1188 & $<0.001$ \\
Histosols & 1.6227 & -1.0109 & 0.59 & 1724.22 & 1,1201 & $<0.001$ \\
Inceptisols & 1.1631 & -0.7331 & 0.52 & 2833.00 & 1,2612 & $<0.001$ \\
Mollisols & 1.0163 & -0.6214 & 0.51 & 2569.03 & 1,2449 & $<0.001$ \\
Spodosols & 1.4262 & -0.9801 & 0.61 & 4097.61 & 1,2581 & $<0.001$ \\
Ultisols & 1.1576 & -0.8867 & 0.68 & 7450.16 & 1,3551 & $<0.001$ \\
Vertisols & 0.5145 & -0.2427 & 0.08 & 9.58 & 1,112 & 0.002 \\
\hline
\end{tabular}

of SOC density observed (1-524 Mg/ha), followed by the West $(n=992)$ with a range of $<1-320 \mathrm{Mg} / \mathrm{ha}$, the Pacific Northwest $(n=430)$ with $8-299 \mathrm{Mg} / \mathrm{ha}$, and the South $(n=833)$ with a range of $3-267 \mathrm{Mg} /$ ha (Fig. 1).

\section{Characterizing the vertical distribution of soil organic carbon}

Many linear and non-linear regression models were evaluated using the ISCN-NFI harmonized data to characterize the vertical distribution of SOC to a depth of $100 \mathrm{~cm}$. These 10 models were evaluated (1) globally, (2) combining all orders, and (3) by soil order. A log-log model [3] provided the best fit to the harmonized data and extra sum of squares $F$ tests (Draper and Smith 1981) confirmed that soil order-specific models were superior to a global model across all orders (Table 2). With the exception of Vertisols and Aridisols, model [3] explained much of the variation in the data with $r^{2}$ ranging from $0.39(P<0.001)$ for Entisols to 0.68 $(P<0.001)$ for Ultisols. The slopes of model [3] are notable, as they characterize the relative rate of decrease in SOC with depth while the intercept characterizes the SOC content (Fig. 2).

\section{Harmonized estimates of soil organic carbon}

The $\mathrm{SOC}_{30}$ estimates, which combined observations from the NFI $(0-20.32 \mathrm{~cm})$ and predictions from the harmonized data set $(20.32-30 \mathrm{~cm})$, ranged from 11 to $541 \mathrm{Mg} / \mathrm{ha}$, with a mean of $67 \pm 0.63 \mathrm{Mg} / \mathrm{ha}$ (Table 3 ). The $\mathrm{SOC}_{100}$ estimates ranged from 40 to $595 \mathrm{Mg} / \mathrm{ha}$, with a mean of $110 \pm 0.69 \mathrm{Mg} / \mathrm{ha}$ (Table 3).

\section{Model evaluation and comparisons}

Country-specific predictions. - Country-specific model predictions of SOC ranged from 20 to $262 \mathrm{Mg} / \mathrm{ha}$, with a mean of $63 \pm 0.66 \mathrm{Mg} /$ ha (Table 1). Histosols had the highest predicted SOC at $144 \pm 6.26 \mathrm{Mg} / \mathrm{ha}$ while Aridisols had the lowest predicted SOC at $29 \pm 1.52 \mathrm{Mg} / \mathrm{ha}$. Regionally, the Northern US had the widest range of SOC predictions (35-262 Mg/ha), followed by the South with a range of $32-173 \mathrm{Mg} / \mathrm{ha}$, the Pacific Northwest with a range of $26-149 \mathrm{Mg} / \mathrm{ha}$, and the West with a range of $20-59 \mathrm{Mg} / \mathrm{ha}$.

Country-specific predictions vs. NFI estimates. -The country-specific model predictions were statistically significantly smaller than $\mathrm{SOC}_{100}$ estimates across all soil orders (Table 4 ), with a mean of the difference between estimates being $-47 \pm 0.89 \mathrm{Mg} / \mathrm{ha}$.

Regionally, the largest differences between the countryspecific model predictions and NFI estimates were in the Western United States $(-83 \pm 1.14 \mathrm{Mg} / \mathrm{ha})$, followed by the
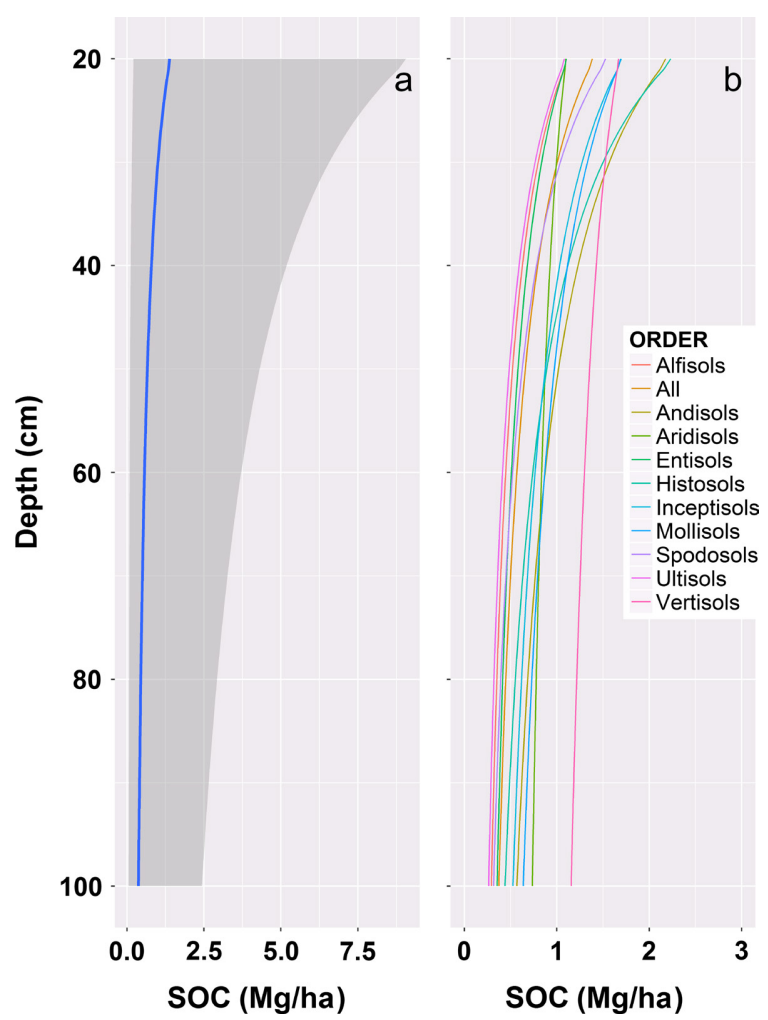

FIG. 2. Characterizations of the model [3] predictions of SOC $(\mathrm{Mg} / \mathrm{ha})$ for all soil orders and associated 95 prediction intervals (a) and individual soil orders (b) from 20.32 to $100 \mathrm{~cm}$. [Colour figure can be viewed at wileyonlinelibrary.com] 
TABLE 3. Summary statistics (mean, minimum [min], and maximum [max]) for $\mathrm{SOC}_{30}$ and $\mathrm{SOC}_{100}(\mathrm{Mg} / \mathrm{ha})$ obtained from the harmonized ISCN-NFI data.

\begin{tabular}{|c|c|c|c|c|c|c|}
\hline \multirow[b]{2}{*}{ Soil order } & \multicolumn{3}{|c|}{$\mathrm{SOC}_{30}$} & \multicolumn{3}{|c|}{$\mathrm{SOC}_{100}$} \\
\hline & Mean & Min & Max & Mean & Min & $\operatorname{Max}$ \\
\hline All & 67.11 & 11.35 & 541.00 & 109.66 & 40.58 & 594.74 \\
\hline Alfisols & 59.84 & 13.09 & 285.89 & 91.41 & 44.66 & 317.46 \\
\hline Andisols & 80.57 & 32.26 & 285.43 & 142.32 & 94.01 & 347.18 \\
\hline Aridisols & 40.15 & 15.75 & 102.57 & 98.30 & 73.90 & 160.72 \\
\hline Entisols & 49.17 & 14.93 & 214.75 & 84.89 & 50.65 & 250.47 \\
\hline Histosols & 81.38 & 37.41 & 287.54 & 134.36 & 90.38 & 340.51 \\
\hline Inceptisols & 80.14 & 16.43 & 541.00 & 133.88 & 70.17 & 594.74 \\
\hline Mollisols & 72.96 & 21.80 & 283.39 & 133.81 & 82.65 & 344.24 \\
\hline Spodosols & 85.94 & 16.01 & 434.34 & 123.25 & 53.33 & 471.66 \\
\hline Ultisols & 56.31 & 11.35 & 243.16 & 85.54 & 40.58 & 272.39 \\
\hline Vertisols & 53.49 & 38.95 & 73.66 & 143.91 & 129.37 & 164.07 \\
\hline
\end{tabular}

Pacific Northwest $(-62 \pm 0.78 \mathrm{Mg} / \mathrm{ha})$, North $(-28 \pm 1.64 \mathrm{Mg} / \mathrm{ha})$, and South $(-27 \pm 1.23 \mathrm{Mg} / \mathrm{ha})($ Fig. 3a).

RF model predictions and NFI estimates. - The RF model [6] explained $38.33 \%$ of the variation in the $\mathrm{SOC}_{100}$ estimates with an RMSE $=4.14 \mathrm{Mg} / \mathrm{ha}$. Relationships between the dependent variable, SOC, and continuous predictor variables identified by RF variable importance (Fig. 4) were also evaluated using Spearman's rank correlation. Latitude was positively correlated with SOC stocks $(0.44, P<0.001)$, as were elevation $(0.27$, $P<0.001)$ and the ratio of precipitation to potential evapotranspiration $(0.22, P<0.001)$. Mean maximum temperature was negatively correlated with SOC $(-0.46$, $P<0.001)$, as were longitude $(-0.12, P<0.001)$ and mean annual precipitation $(-0.09, P<0.001)$.

Equivalence tests for the mean of the difference between RF model [6] predictions and $\mathrm{SOC}_{100}$ estimates were conducted for all soil orders and individual orders to further evaluate RF model performance. The mean of the differences between RF model predictions and $\mathrm{SOC}_{100}$ estimates across all orders was $-0.15 \pm 0.26 \mathrm{Mg} / \mathrm{ha}$ and these estimates were statistically equivalent (Table 4). With the exception of the Vertisols, Histosols, and Aridisols, which all had relatively small sample sizes $(n=9,30$, and 112 , respectively), all other RF model predictions and NFI estimates were statistically equivalent, with the smallest differences in the Ultisols $(-0.25 \pm 0.45 \mathrm{Mg} / \mathrm{ha})$, Inceptisols $(-0.33 \pm 0.90 \mathrm{Mg} / \mathrm{ha})$, and Spodosols $(-0.50 \pm 1.02 \mathrm{Mg} /$ ha). Regionally, the mean of the differences between RF model predictions and $\mathrm{SOC}_{100}$ estimates of $\mathrm{C}$ density were relatively small, with the largest differences in the Pacific Northwest $(0.63 \pm 0.78 \mathrm{Mg} / \mathrm{ha})$ followed by the South $(0.60 \pm 0.33 \mathrm{Mg} / \mathrm{ha})$, West $(-0.36 \pm 0.48 \mathrm{Mg} / \mathrm{ha})$, and North $(-0.26 \pm 0.49 \mathrm{Mg} /$ ha; Fig. $3 b)$. The RF model predictions were then applied to all NFI plots in the conterminous United States with at least one forested condition (Figs. 5, 6).

RaCA and RF model comparisons.-RF model predictions at 30 and $100 \mathrm{~cm}$ were substantially smaller than RaCA (Soil Survey Staff 2013) estimates in most LRRs in the United States (Table 5). The largest differences were in the Florida Subtropical Fruit, Truck Crop, and Range Region at both 30 and $100 \mathrm{~cm}(-239 \%$ and $-412 \%$, respectively), followed by the Northern Lake States Forest and Forage Region ( $-224 \%$ and $-327 \%$, respectively), and the Atlantic and Gulf Coast Lowland Forest and Crop Region $(-212 \%$ and $-317 \%$, respectively). There was generally better agreement between mean SOC density $(\mathrm{Mg} / \mathrm{ha})$

TABLE 4. Equivalence test results of SOC density $(\mathrm{Mg} / \mathrm{ha})$ by soil order.

\begin{tabular}{|c|c|c|c|c|c|c|}
\hline \multirow[b]{2}{*}{ Soil order } & \multicolumn{3}{|c|}{ Country-specific, NFI } & \multicolumn{3}{|c|}{ Random forests, NFI } \\
\hline & Mean & SE & TOST & Mean & SE & TOST \\
\hline All orders & -46.96 & 0.89 & NE & -0.15 & 0.26 & $\mathrm{E}$ \\
\hline Alfisols & -32.27 & 1.44 & $\mathrm{NE}$ & -0.68 & 0.42 & $\mathrm{E}$ \\
\hline Andisols & -72.93 & 3.66 & NE & 1.39 & 1.40 & $\mathrm{E}$ \\
\hline Aridisols & -69.67 & 2.23 & $\mathrm{NE}$ & 0.73 & 0.74 & $\mathrm{NE}$ \\
\hline Entisols & -33.99 & 3.00 & $\mathrm{NE}$ & -0.77 & 0.79 & $\mathrm{E}$ \\
\hline Histosols & -22.68 & 9.48 & NE & 1.89 & 4.10 & $\mathrm{NE}$ \\
\hline Inceptisols & -67.69 & 2.63 & $\mathrm{NE}$ & -0.33 & 0.90 & $\mathrm{E}$ \\
\hline Mollisols & -86.65 & 1.60 & NE & 0.70 & 0.57 & $\mathrm{E}$ \\
\hline Spodosols & -17.17 & 3.19 & $\mathrm{NE}$ & -0.50 & 1.02 & $\mathrm{E}$ \\
\hline Ultisols & -28.17 & 1.36 & $\mathrm{NE}$ & -0.25 & 0.45 & $\mathrm{E}$ \\
\hline Vertisols & -96.56 & 5.64 & $\mathrm{NE}$ & 6.75 & 2.26 & $\mathrm{NE}$ \\
\hline
\end{tabular}

Note: Mean, mean difference; SE, standard error of the mean difference; and TOST, two-one-sided test results where NE is not equivalent and $\mathrm{E}$ is equivalent and the absolute value of the mean of the differences is $\pm 25 \%$ of the standard deviation. 


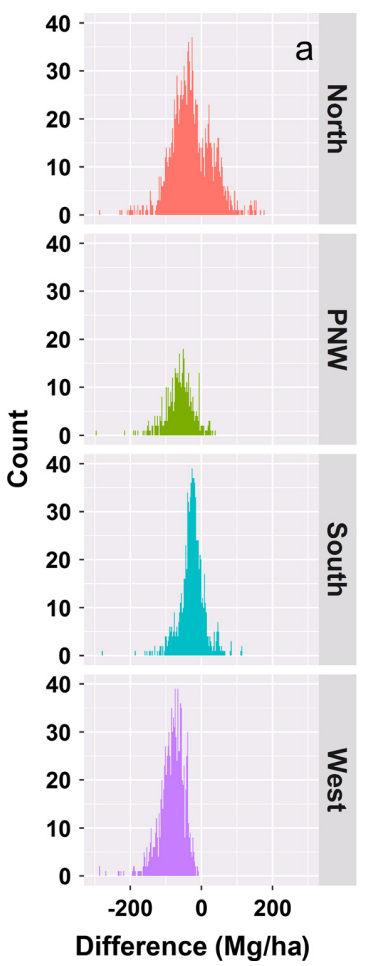

FIG. 3. Differences between (a) country-specific model predictions and NFI-ISCN harmonized estimates of SOC stocks and (b) random forests model predictions and NFIISCN harmonized estimates of SOC stocks. Note that differences are in $\mathrm{Mg} / \mathrm{ha}$. [Colour figure can be viewed at wileyonlinelibrary.com]

estimates from RaCA and RF at $100 \mathrm{~cm}$ than at $30 \mathrm{~cm}$ across the LRRs. Estimates were most similar at 30 and $100 \mathrm{~cm}$ in the Central Feed Grains and Livestock Region ( $7 \%$ and $-1 \%$, respectively), the Northern Great Plains Spring Wheat Region (-14\%), and the Western Range and Irrigated Region ( $-17 \%$ and $13 \%$, respectively).

\section{Discussion}

Estimates of SOC concentration are typically quite variable over space and time (Homann et al. 2001, Ellert et al. 2002), with potentially large differences in development between forest types on the same soils (Ladegaard-Pedersen et al. 2005) and depths at short distances (Smit 1999). Compounding the very real variability that exists in SOC is the difficulty of obtaining representative measurements of bulk density, which are required to compute SOC stocks (Lee et al. 2009), as well as accurate representation of soil depth and coarse fragment content. This variability complicates not only the inventories of soil attributes but also the prediction of SOC stocks in inventories lacking soil measurements, especially when large observational data sets, developed over institutional timeframes, are used for predictive purposes not anticipated during their original design. For example, in computing SOC stocks from NRCS and
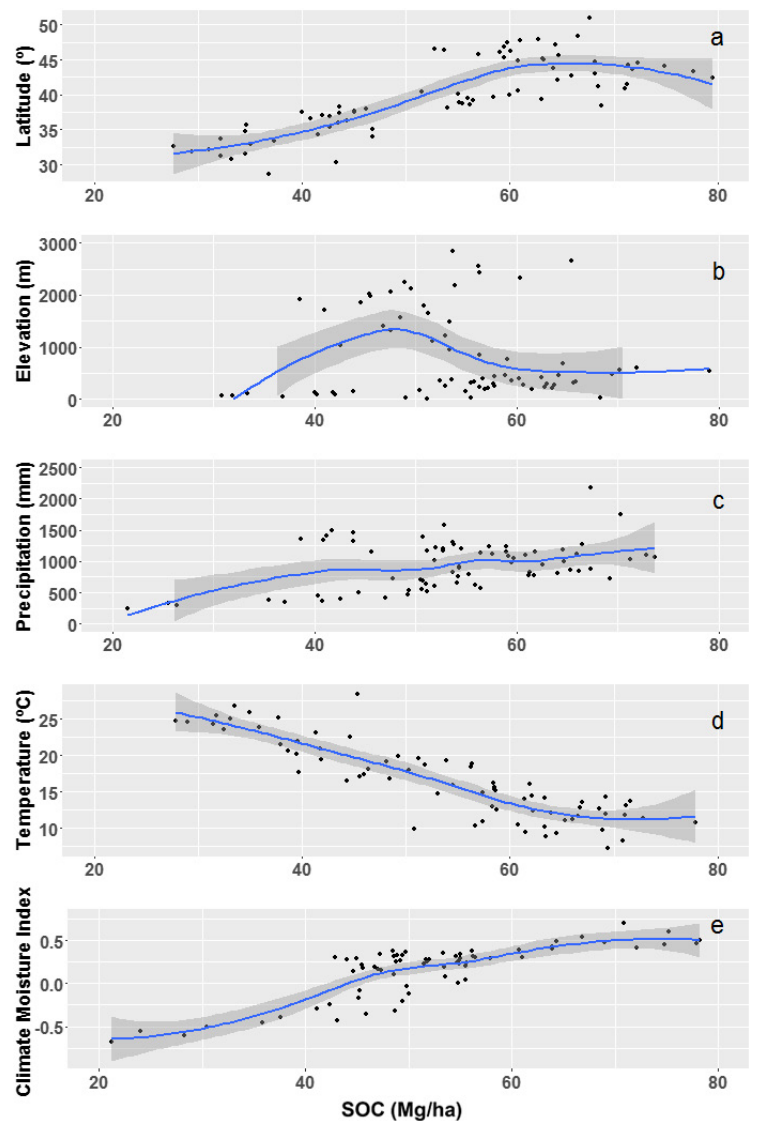

FIG. 4. Relationships between the dependent variable, SOC, and continuous predictor variables identified by random forests variable importance: a) is latitude (degrees), b) is elevation (m), c) is mean annual precipitation ( $\mathrm{mm})$, d) is average maximum temperature (degrees C), and e) is climate moisture index expressed as the ratio of precipitation to potential evapotranspiration. [Colour figure can be viewed at wileyonlinelibrary.com]

other contributor data, the ISCN database utilizes any available bulk density and coarse fragment data, determined by a range of different methods, in order to maximize the availability of SOC stock estimates. Utilizing a range of different scaling metrics introduces unquantified uncertainty into the resulting SOC stock estimates; however, the new estimation and reporting framework described here provides a basis for future sensitivity analyses and iterative improvements to the process. At the scale of this analysis, it is likely that other sources of variation, including those identified through RF modeling, are more important drivers of variation in SOC content than are variable methods used in soil bulk density or coarse fragment determination. Indeed, comparing SOC estimates from NFI measurements and ISCN data for Spodosols and Alfisols to 10 and $20 \mathrm{~cm}$ depths show only 5-15\% differences, despite differences in the bulk density methods used for NFI and ISCN (NRCS) data. Ultimately, by replacing the countryspecific model with real physical observations, our approach represents improvement in national estimation 


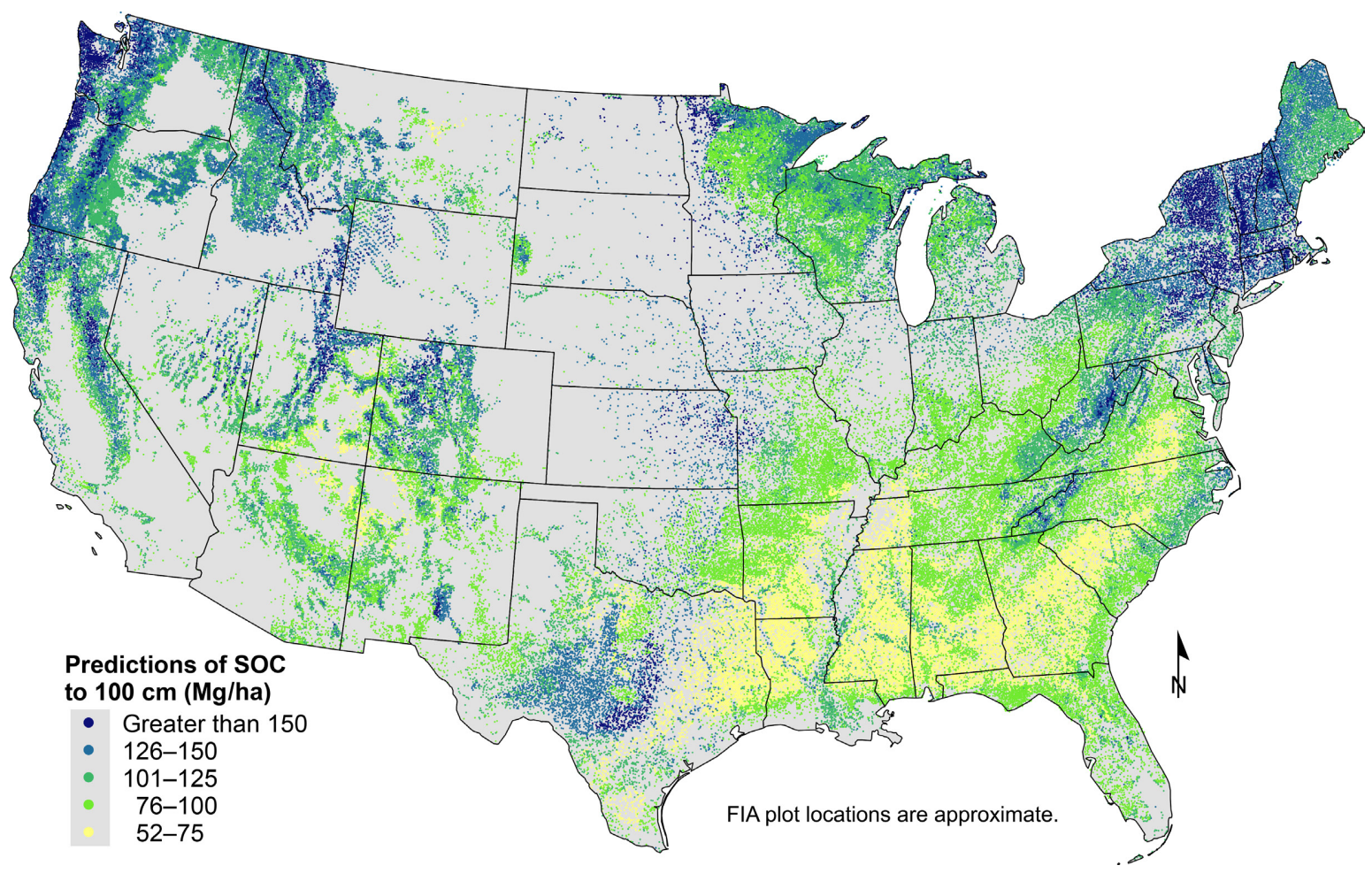

FIG. 5. Random forests model predictions of SOC stocks $(0-100 \mathrm{~cm})$ for all NFI plots with at least one forest land condition in the conterminous United States. [Colour figure can be viewed at wileyonlinelibrary.com]

of historical SOC stocks per $\mathrm{C}$ baseline reporting requirements (e.g., the year 1990 baseline in United Nations Framework Convention of Climate Change reporting). In general, the IPCC guidelines for National Greenhouse Gas Inventories suggest that countries use estimation methods consistent with their resources and, when properly implemented, they should provide unbiased estimates of emissions and sinks (IPCC 2006).

In the United States, the country-specific model may be defined as a Tier 2 estimation method since it relies on activity data specific to the United States by major forest type and includes other important country-specific variables that may influence soil forming factors but does not directly rely on soil attributes measured in an inventory system (IPCC 2006). When the country-specific model was developed, soil attributes were only beginning to be measured in the NFI and these data were not sufficient to evaluate the accuracy and precision of the country-specific model predictions, but, since it relied on information from the STATSGO database, the model predictions were assumed to be accurate. In fact, country-specific model predictions (to a depth of $100 \mathrm{~cm}$ ) are well below default SOC stocks for temperate ecosystems specified in the IPCC Good Practice Guidelines to a depth of $30 \mathrm{~cm}$. The IPCC (2006) defaults range from $19 \mathrm{Mg} /$ ha in sandy soils at warm, dry locations to $130 \mathrm{Mg} /$ ha in volcanic soils (i.e., Andisols) at cold and moist locations (IPCC 2006).

With an extensive sample of SOC densities across a national plot network on forest land in the US (USDA
Forest Service 2017), it is now possible to evaluate the country-specific predictions. It is not surprising that the country-specific model predictions did not fit the NFI data well, given the high variability observed in SOC stock estimates in this study and the literature (Webster and Oliver 1990, Smit 1999, Yanai et al. 2000, Böttcher and Springob 2001, Schulp et al. 2008) and the fact the country-specific model was developed while SOC sampling in the NFI was in its infancy. In general, the countryspecific model produced predictions with a substantial downward bias, resulting in statistically significant differences between NFI estimates and the country-specific model across all soil orders. The large differences between NFI estimates and the country-specific model can be attributed to several factors. First, the country-specific model was developed using STATSGO data, which has a wide distribution but much of the data is from non-forest land and estimates of SOC are averages over large map units intended for broad planning and management uses covering state, regional, and multi-state areas and are not expected to provide accurate estimates of SOC for specific locations (Homann et al. 2005). Second, SOC estimates were used by broad forest type in the country-specific model whereas plot-specific $\mathrm{C}$ content and bulk density measurements were used to obtain estimates of SOC from the NFI. Finally, given the high variability observed in SOC estimates, it is likely that the country-specific model did not include important interactions between the variables included in the RF model as well as other variables 


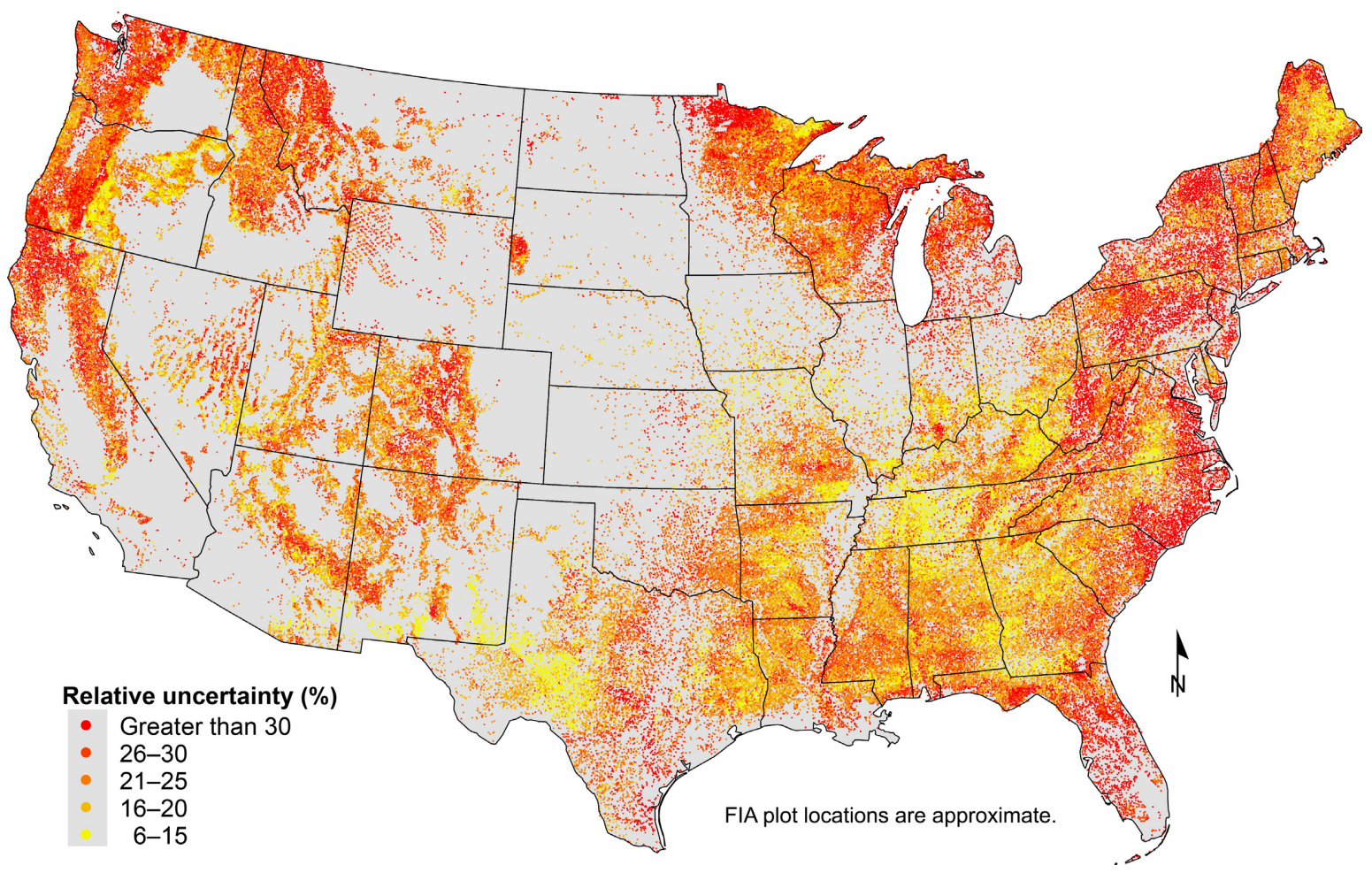

FIG. 6. Relative uncertainty (the ratio between the $95 \%$ confidence interval and the mean of the regression trees from the random forest) of the random forest predictions of SOC stocks $(0-100 \mathrm{~cm})$ for all NFI plots with at least one forest land condition in the conterminous United States. [Colour figure can be viewed at wileyonlinelibrary.com]

(e.g., temperature, precipitation) that directly and indirectly influence SOC dynamics (Jobbágy and Jackson 2000, Parton et al. 2007). Models of SOC that are sensitive to climate variables, physiographic factors, and vegetation type are consistent with our understanding of soil formation (Jenny 1941, McBratney et al. 2003, Thompson and Kolka 2005, Mishra et al. 2010, Woldeselassie et al. 2012, Tian et al. 2015).

TABLE 5. Comparison of RF model predictions and NRCS Rapid Assessment of U.S. Soil Carbon (RaCA) estimates of SOC at 30 and $100 \mathrm{~cm}$ by NRCS Land Resource Regions (LRRs).

\begin{tabular}{|c|c|c|c|c|c|c|}
\hline \multirow[b]{2}{*}{ Land resource region } & \multicolumn{2}{|c|}{$30 \mathrm{~cm}$} & \multirow{2}{*}{$\begin{array}{l}\text { Difference } \\
\quad(\%)\end{array}$} & \multicolumn{2}{|c|}{$100 \mathrm{~cm}$} & \multirow{2}{*}{$\begin{array}{l}\text { Difference } \\
\quad(\%)\end{array}$} \\
\hline & $\mathrm{RaCA}$ & RF & & $\mathrm{RaCA}$ & $\mathrm{RF}$ & \\
\hline Northwestern Forest, Forage, and Specialty Crop & 188.58 & 80.43 & -134 & 269.76 & 132.01 & -104 \\
\hline Northwestern Wheat and Range & 64.33 & 79.84 & 19 & 85.73 & 138.39 & 38 \\
\hline $\begin{array}{l}\text { California Subtropical Fruit, Truck, and Specialty } \\
\text { Crop }\end{array}$ & 87.45 & 57.88 & -51 & 122.92 & 106.27 & -16 \\
\hline Western Range and Irrigated & 63.88 & 54.77 & -17 & 89.78 & 103.21 & 13 \\
\hline Rocky Mountain Range and Forest & 90.63 & 72.21 & -26 & 129.37 & 125.34 & -3 \\
\hline Northern Great Plains Spring Wheat & 122.93 & 107.38 & -14 & 188.11 & 164.57 & -14 \\
\hline Western Great Plains Range and Irrigated & 70.41 & 56.77 & -24 & 114.70 & 100.90 & -14 \\
\hline Central Great Plains Winter Wheat and Range & 79.90 & 51.00 & -57 & 130.29 & 98.65 & -32 \\
\hline Southwest Plateaus and Plains Range and Cotton & & 67.55 & & & 122.37 & \\
\hline Southwestern Prairies Cotton and Forage & 65.21 & 51.75 & -26 & 93.01 & 96.46 & 4 \\
\hline Northern Lake States Forest and Forage & 233.15 & 72.01 & -224 & 478.95 & 112.17 & -327 \\
\hline Lake State Fruit, Truck Crop, and Dairy & 135.05 & 78.70 & -72 & 324.08 & 116.59 & -178 \\
\hline Central Feed Grains and Livestock & 65.20 & 70.35 & 7 & 110.99 & 110.12 & -1 \\
\hline East and Central Farming and Forest & 93.26 & 62.44 & -49 & 126.31 & 95.11 & -33 \\
\hline Mississippi Delta Cotton and Feed Grains & 61.65 & 34.61 & -78 & 93.06 & 73.37 & -27 \\
\hline $\begin{array}{l}\text { South Atlantic and Gulf Slope Cash Crops, Forest, } \\
\text { and Livestock }\end{array}$ & 78.23 & 40.93 & -91 & 113.31 & 71.28 & -59 \\
\hline Northeastern Forage and Forest & 256.65 & 100.02 & -157 & 438.06 & 142.43 & -208 \\
\hline Northern Atlantic Slope Diversified Farming & 165.24 & 81.62 & -102 & 200.67 & 119.65 & -68 \\
\hline Atlantic and Gulf Coast Lowland Forest and Crop & 213.32 & 68.31 & -212 & 415.40 & 99.63 & -317 \\
\hline Florida Subtropical Fruit, Truck Crop, and Range & 185.78 & 54.74 & -239 & 475.53 & 92.84 & -412 \\
\hline
\end{tabular}


Given the large investment in sampling SOC attributes, it is now possible to transition from the biased Tier 2 estimates of SOC density to a Tier 3 approach, which links availability of SOC observations in the NFI to the geophysical and climate relationships identified in SOC studies (Jobbágy and Jackson 2000, Wardle et al. 2004, Parton et al. 2007, Thompson and Kolka 2005, Tian et al. 2015) and available as ancillary data. The modeling framework using RF allowed us to select from a large suite of biotic and abiotic variables with potentially complex interactions and develop a model that fit the NFI data reasonably well, particularly when compared to the country-specific model. The RF estimates of SOC to a depth of $100 \mathrm{~cm}$ were well within the range of SOC estimates found in other studies in temperate forest ecosystems (Mattson and Swank 1989, Harding and Jokela 1994, Jobbágy and Jackson 2000, Thompson and Kolka 2005, Woldeselassie et al. 2012, Tian et al. 2015, De Vos et al. 2015).

There are several advances and advantages to this modeling framework over the country-specific model. First and foremost, it was fit using observations of SOC stocks obtained directly from samples in the NFI. This improved both the accuracy and precision of the model predictions used to compile estimates. Second, the RF modeling framework included region- to site-level variables that are congruent with known, broad-scale drivers of SOC storage, and enhance the predictive capacity of the model at a scale (plot) more compatible with spatially explicit NFI and ISCN data. For example, empirical relationships between SOC, temperature, and precipitation reflect global to regional patterns in SOC stocks as a function of climate (Post et al. 1982, Jobbágy and Jackson 2000). Inclusion of these climate variables as continuous predictors in the model allows for better spatially explicit prediction, and, ultimately, aggregation of SOC estimates over larger scales for $\mathrm{C}$ reporting. As another example, consider model results showing different amounts and vertical distribution of SOC for soils of different taxonomic order. This reflects the variability in pedogenesis across distinct soils, which may be located in close association of one another. For instance, model predictions for Alfisols and Mollisols, which occur as associations in areas of interspersed grassland-woodland ecosystems, show very similar surface SOC stocks but markedly different depth distributions (Masiello et al. 2004, Abella et al. 2013). Spodosols and Entisols likewise co-occur, especially in young, glaciated, northern landscapes (Hunckler and Schaetzl 1997, Schaetzl 2002). Model results identified Spodosols as having among the highest surface SOC stocks, Entisols among the lowest, and the two differing widely in their SOC depth distributions. Last, Andisols and Aridisols co-occur in volcanic, mountainous regions with steep climatic gradients (McAuliffe 1994, Biedenbender et al. 2004); the deep, reactive Andisols were second only to Histosols (organic soils) in SOC stocks at the surface, but show a more even distribution of $\mathrm{C}$ with depth, while the Aridisols showed the lowest and least depth-dependent SOC stocks of all orders. Ultimately, the ability of the model to duplicate real differences in the depth distribution of SOC across soil orders is not only interesting from a pedogenetic perspective, but useful in terms of forecasting SOC change and vulnerability for future efforts. For example, mechanical disturbance or erosion influence the depth distribution of SOC, with consequences not only for the total amount of SOC stored but also its turnover time (Franzluebbers 2002, Rosenbloom et al. 2006). Third, the modeling framework is easily adapted to accommodate data limitations over the United Nations Framework Convention of Climate Change reporting period and updated as new information becomes available. This is particularly important as remeasurements of SOC attributes at existing NFI plots become available.

While the modeling framework described in this study represents an improvement toward estimating SOC stocks and stock changes from forest land in National Greenhouse Gas Inventories of the United States, the SOC pool is highly variable, both vertically and horizontally, and much uncertainty remains. The strategic application of the new modeling framework required data sources that were available across the entire conterminous United States. With that limitation, the RF model explained $38 \%$ of the variation in the SOC observations; some variables and interactions are not being captured in the new framework. Standardizing SOC sampling procedures so that measurements could be used across studies and compared between studies would be useful to identify just how much variation can be explained in modeling exercises and at what spatial resolution. Finally, the lack of remeasurements in the NFI limit the evaluation of stock change estimates at this time. As remeasurements become available, the existing methods for SOC prediction can be evaluated and new change variables can be identified that may improve predictions and the sensitivity of models to characterize SOC stocks and stock changes.

\section{Conclusions}

Four conclusions were drawn from this study. First, the country-specific model used to predict SOC stocks and stock changes in forests of the United States grossly underestimated the contribution of this pool in recent U.S. submissions to the United Nations Framework Convention on Climate Change. Second, log-log models fit by soil order adequately characterized SOC observations across depth from the harmonized NFI and ISCN data. Third, RF for regression and variable selection is an effective and computationally efficient approach for predicting SOC stocks for NFI plots lacking soil observations. Fourth, the new modeling framework for SOC estimation produced statistically equivalent predictions of SOC for NFI plots with soil measurements for all but three soil orders, which were not well represented in the sample. The modeling framework described in this study represents in an improvement toward the estimation of 
SOC stocks in forests of the United States. That said, the SOC pool in forests of the United States is highly variable and much uncertainty remains.

\section{ACKNOWLEDGMENTS}

The authors would like to thank Chuck Bulmer, Robert Slesak, and John Stanovick for helpful comments that improved an earlier version of this manuscript. They would also like to thank the Subject Matter Editor and two anonymous reviewers for comments and suggestions that also greatly improved the manuscript.

\section{Literature Cited}

Abella, S. R., C. W. Denton, R. W. Steinke, and D. G. Brewer. 2013. Soil development in vegetation patches of Pinus ponderosa forests: interface with restoration thinning and carbon storage. Forest Ecology and Management 310:632-642.

Amacher, M. C., K. P. O'Neill, R. Dresbach, and C. Palmer. 2003. Forest inventory and analysis manual of soil analysis methods. http://www.nrs.fs.fed.us/fia/topics/soils/documents/ FIA.P3.Soils.Lab.Manual.2003.pdf

Amichev, B. Y., and J. M. Galbraith. 2004. A revised methodology for estimation of forest soil carbon from spatial soils and forest inventory data sets. Environmental Management 33:S74-S86.

Biedenbender, S. H., M. P. McClaran, J. Quade, and M. A. Weltz. 2004. Landscape patterns of vegetation change indicated by soil carbon isotope composition. Geoderma 119: 69-83.

Böttcher, J., and G. Springob. 2001. A carbon balance model for organic layers of acid forest soils. Journal of Plant Nutrition and Soil Science 164:399-405.

Breiman, L. 2001. Random forests. Machine Learning 45:5-32.

Danielson, J. J., and D. B. Gesch. 2011. Global multi-resolution terrain elevation data 2010 (GMTED2010): U.S. Geological Survey. Open-File Report 2011-1073. Page 26. https://pubs. usgs.gov/of/2011/1073/

Davidson, E. A., and I. A. Janssens. 2006. Temperature sensitivity of soil carbon decomposition and feedbacks to climate change. Nature 440:165-173.

De Vos, B., N. Cools, H. Ilvesniemi, L. Vesterdal, E. Vanguelova, and S. Carnicelli. 2015. Benchmark values for forest soil carbon stocks in Europe: results from a large scale forest soil survey. Geoderma 251:33-46.

Domke, G. M., C. H. Perry, B. F. Walters, C. W. Woodall, M. B. Russell, and J. E. Smith. 2016. Estimating litter carbon stocks on forest land in the United States. Science of the Total Environment 557:469-478.

Draper, N., and H. Smith. 1981. Applied regression analysis. Second edition. Wiley, New York, New York, USA.

Ellert, B. H., H. H. Janzen, and T. Entz. 2002. Assessment of a method to measure temporal change in soil carbon storage. Soil Science Society of America Journal 66:1687-1695.

Franzluebbers, A. J. 2002. Soil organic matter stratification ratio as an indicator of soil quality. Soil \& Tillage Research 66:95-106.

Guo, L. B., and R. M. Gifford. 2002. Soil carbon stocks and land use change: a meta analysis. Global Change Biology 8:345-360.

Harding, R. B., and E. J. Jokela. 1994. Long-term effects of forest fertilization on site organic matter and nutrients. Soil Science Society of America Journal 58:216-221.

Heimann, M., and M. Reichstein. 2008. Terrestrial ecosystem carbon dynamics and climate feedbacks. Nature 451: 289-292.
Homann, P. S., B. T. Bormann, and J. R. Boyle. 2001. Detecting treatment differences in soil carbon and nitrogen resulting from forest manipulations. Soil Science Society of America Journal 65:463-469.

Homann, P. S., M. Harmon, S. Remillard, and E. A. Smithwick. 2005. What the soil reveals: potential total ecosystem C stores of the Pacific Northwest region, USA. Forest Ecology and Management 220:270-283.

Homann, P. S., P. Sollins, M. Fiorella, T. Thorson, and J. S. Kern. 1998. Regional soil organic carbon storage estimates for western Oregon by multiple approaches. Soil Science Society of America Journal 62:789-796.

Homer, C. H., J. A. Fry, and C. A. Barnes. 2012. The national land cover database. U.S. Geological Survey Fact Sheet 3020. U.S. Geological Survey, Reston, Virginia, USA

Hunckler, R. V., and R. J. Schaetzl. 1997. Spodosol development as affected by geomorphic aspect, Baraga County, Michigan. Soil Science Society of America Journal 61: $1105-1115$.

IPCC. 2006. 2006 IPCC guidelines for National Greenhouse Gas Inventories. In H. S. Eggleston, L. Buendia, K. Miwa, T. Ngara, and K. Tanabe, editors. The National Greenhouse Gas Inventories Programme, The Intergovernmental Panel on Climate Change. Hayama, Kanagawa, Japan. www.ipccnggip.iges.or.jp/public/2006gl/index.html

International Soil Carbon Network. 2012a. ISCN Generation 2 Database report: site and profile information. http://bwc.lbl. gov/StaticReports/ISCN/SiteProfile_LATEST.xls

International Soil Carbon Network. 2012b. ISCN Generation 2 Database report: Per-layer data. http://bwc.lbl.gov/ StaticReports/ISCN/ISCNLayerData_LATEST.xlsx

Jandl, R., et al. 2014. Current status, uncertainty and future needs in soil organic carbon monitoring. Science of the Total Environment 468:376-383.

Jenny, H. 2012. The soil resource: origin and behavior. Volume 37. Springer Science \& Business Media.

Jobbágy, E. G., and R. B. Jackson. 2000. The vertical distribution of soil organic carbon and its relation to climate and vegetation. Ecological Applications 10:423-436.

Keith, H., B. G. Mackey, and D. B. Lindenmayer. 2009. Re-evaluation of forest biomass carbon stocks and lessons from the world's most carbon-dense forests. Proceedings of the National Academy of Sciences USA 106: $11635-11640$.

Kurz, W. A., and M. J. Apps. 2006. Developing Canada's national forest carbon monitoring, accounting and reporting system to meet the reporting requirements of the Kyoto Protocol. Mitigation Adaption Strategies for Global Change 11:33-43.

Ladegaard-Pedersen, P., B. Elberling, and L. Vesterdal. 2005. Soil carbon stocks, mineralization rates, and $\mathrm{CO} 2$ effluxes under 10 tree species on contrasting soil types. Canadian Journal of Forest Research 35:1277-1284.

Lal, R. A. T. T. A. N. 2001. Soil degradation by erosion. Land Degradation \& Development 12:519-539.

Lal, R. 2004. Soil carbon sequestration impacts on global climate change and food security. Science 304:1623-1627.

Lal, R. 2005. Forest soils and carbon sequestration. Forest Ecology and Management 220:242-258.

Lee, J., J. W. Hopmans, D. E. Rolston, S. G. Baer, and J. Six. 2009. Determining soil carbon stock changes: simple bulk density corrections fail. Agriculture Ecosystems and Environment 134:251-256.

Masiello, C. A., O. A. Chadwick, J. Southon, M. S. Torn, and J. W. Harden. 2004. Weathering controls on mechanisms of carbon storage in grassland soils. Global Biogeochemical Cycles 18(4):1-9. 
Mattson, K. G., and W. T. Swank. 1989. Soil and detrital carbon dynamics following forest cutting in the Southern Appalachians. Biology and Fertility of Soils 7:247-253.

McAuliffe, J. R. 1994. Landscape evolution, soil formation, and ecological patterns and processes in Sonoran Desert Bajadas. Ecological Monographs 64:111-148.

McBratney, A. B., M. M. Santos, and B. Minasny. 2003. On digital soil mapping. Geoderma 117:3-52.

Mishra, U., R. Lal, D. Liu, and M. Van Meirvenne. 2010. Predicting the spatial variation of the soil organic carbon pool at a regional scale. Soil Science Society of America Journal 74:906-914.

Multi-Resolution Land Characteristics Consortium. 2011. 2001 National land cover data (NLCD 2001). U.S. Geologic Survey, Reston, Virginia, USA. http://www.mrlc.gov/

Nave, L. E., E. D. Vance, C. W. Swanston, and P. S. Curtis. 2010. Harvest impacts on soil carbon storage in temperate forests. Forest Ecology and Management 259:857-866.

Nave, L. E., C. W. Swanston, U. Mishra, and K. J. Nadelhoffer. 2013. Afforestation effects on soil carbon storage in the United States: a synthesis. Soil Science Society of America Journal 77:1035-1047.

O’Neill, K. P., M. C. Amacher, and C. H. Perry. 2005. Soils as an indicator of forest health: a guide to the collection, analysis, and interpretation of soil indicator data in the Forest Inventory and Analysis program. General Technical Report NC-258. US Department of Agriculture, Forest Service, North Central Research Station, St. Paul, Minnesota, USA.

Parton, W., et al. 2007. Global-scale similarities in nitrogen release patterns during long-term decomposition. Science 315:361-364.

Post, W. M., W. R. Emanuel, P. J. Zinke, and A. G. Stangenberger. 1982. Soil carbon pools and world life zones. Nature 298:156-159.

R Development Core Team. 2014. R: a language and environment for statistical computing. R Foundation for Statistical Computing, Vienna, Austria. http://www.R-project.org/

Rosenbloom, N. A., J. W. Harden, J. C. Neff, and D. S. Schimel. 2006. Geomorphic control of landscape carbon accumulation. Journal of Geophysical Research: Biogeosciences 111(G1):1-10.

Schaetzl, R. J. 2002. A spodosol-entisol transition in northern Michigan. Soil Science Society of America Journal 66:1272-1284.

Schulp, C. J., G. J. Nabuurs, P. H. Verburg, and R. W. de Waal. 2008. Effect of tree species on carbon stocks in forest floor and mineral soil and implications for soil carbon inventories. Forest ecology and management 256:482-490.

Schwarz, G. E., and R. B. Alexander. 1995. State soil geographic (STATSGO) data base for the conterminous United States (No. 95-449). https://pubs.er.usgs.gov/publication/ofr95449

Sikora, L. J. and D. E. Stott. 1996. Soil organic carbon and nitrogen. Pages 157-168 in J. W. Doran and A. J. Jones, editors. Methods for assessing soil quality. Soil Science Society of America, Madison, Wisconsin, USA.

Smit, A. 1999. The impact of grazing on spatial variability of humus profile properties in a grass-encroached Scots pine ecosystem. Catena 36:85-98.

Soil Survey Staff. 1999. Soil taxonomy: A basic system of soil classification for making and interpreting soil surveys. Second edition. Natural Resources Conservation Service, U.S. Department of Agriculture Handbook 436, Washington, D.C., USA.

Soil Survey Staff. Rapid Carbon Assessment (RaCA) Project. 2013. United States Department of Agriculture, Natural
Resources Conservation Service. https://www.nrcs.usda. gov/wps/portal/nrcs/detail/soils/survey/?cid=nrcs142p2_ 054164

Sprugel, D. G. 1983. Correcting for bias in log-transformed allometric equations. Ecology 64:209-210.

Thompson, J. A., and R. K. Kolka. 2005. Soil carbon storage estimation in a forested watershed using quantitative soillandscape modeling. Soil Science Society of America Journal 69:1086-1093.

Tian, H., et al. 2015. Global patterns and controls of soil organic carbon dynamics as simulated by multiple terrestrial biosphere models: current status and future directions. Global Biogeochemical Cycles 29:775-792.

U.S. Environmental Protection Agency (U.S. EPA). 2015. Forest sections of the land use, land use change, and forestry chapter, and Annex in US Environmental Protection Agency, Inventory of US Greenhouse Gas Emissions and Sinks: 1990-2014. EPA 430-R-15-004. U.S. EPA, Washington, D.C., USA.

USDA Farm Agriculture Service. 2011. National Agriculture Imagery Program (NAIP). https://www.fsa.usda.gov/pro grams-and-services/aerial-photography/imagery-programs/ naip-imagery/index

USDA Forest Service. 2011. Phase 3 field guide-soil measurements and sampling. V5.1. http://www.fia.fs.fed.us/library/ field-guides-methods-proc/docs/2012/field_guide_p3_5-1_ sec22_10_2011.pdf

USDA Forest Service. 2015. Forest inventory and analysis national core field guide. Volume I: field data collection procedures for phase 2 plots. V6.1. . http://www.fia.fs.fed.us/ library/field-guides-methods-proc/docs/2015/Core-FIAFG-7.pdf

USDA Forest Service. 2016. The forest inventory and analysis database: database description and user guide for phase 2 (version 6.0.2). http://www.fia.fs.fed.us/library/database-doc umentation/current/ver60/FIADB $\% 20$ User $\% 20$ Guide $\% 20$ P2_6-0-2_final-opt.pdf

USDA Forest Service. 2017. Forest Inventory and Analysis Database (FIADB) version 7.0. http://apps.fs.fed.us/fiadbdownloads/datamart.html.

USDA NRCS. 2006. Land resource regions and major land resource areas of the United States, the Caribbean, and the Pacific Basin. U.S. Department of Agriculture Handbook 296. https://www.nrcs.usda.gov/wps/portal/nrcs/detail/soils/ survey/?cid=nrcs142p2_053624

Wardle, D. A., R. D. Bardgett, J. N. Klironomos, H. Setälä, W. H. Van Der Putten, and D. H. Wall. 2004. Ecological linkages between aboveground and belowground biota. Science 304(5677):1629-1633.

Webster, R., and M. A. Oliver. 1990. Statistical methods in soil and land resource survey. Oxford University Press (OUP), Oxford, UK.

Wellek, S. 2003. Testing statistical hypotheses of equivalence. Chapman \& Hall, London, UK.

Woldeselassie, M., H. Van Miegroet, M. C. Gruselle, and N. Hambly. 2012. Storage and stability of soil organic carbon in aspen and conifer forest soils of northern Utah. Soil Science Society of America Journal 76:2230-2240.

Yanai, R. D., M. A. Arthur, T. G. Siccama, and C. A. Federer. 2000. Challenges of measuring forest floor organic matter dynamics: Repeated measures from a chronosequence. Forest Ecology and Management 138:273-283.

Zushi, K. 2006. Spatial distribution of soil carbon and nitrogen storage and forest productivity in a watershed planted to Japanese cedar (Cryptomeria japonica D. Don). Journal of Forest Research 11:351-358. 